\title{
PERSEPSI PEMILIH MILENIAL DALAM PEMILU SERENTAK 2019 DI PROVINSI DAERAH ISTIMEWA YOGYAKARTA
}

\author{
Moch. Edward Trias Pahlevi \\ Peneliti Komite Independen Sadar Pemilu \\ Jalan Randu, RT 4/5 Mejing Wetan, Ambarketawang, Gamping, Sleman, \\ Daerah Istimewa Yogyakarta \\ mochedwaardtriaspahlevi@gmail.com \\ Wildhan Khalyubi \\ Mahasiswa Magister IImu Politik Universitas Indonesia \\ Gedung B (Tapi Omas Ihromi) Lantai 2 Fakultas IImu Sosial dan IImu Politik \\ Universitas Indonesia, Depok, Jawa Barat \\ wildhan.khalyub@gmail.com \\ Muhammad Iqbal Khatami \\ Mahasiswa Ilmu Komunikasi Universitas Muhammadiyah Yogyakarta \\ Kampus Terpadu UMY, Jl. Brawijaya, Kasihan, Kabupaten Bantul, Daerah Istimewa \\ Yogyakarta \\ iqbalkhatami1998@gmail.com
}

\begin{abstract}
The 2019 General Elections are legislative elections and presidential elections that are held simultaneously on the same day. This is done by the Constitutional Court Decision Number 14/PUU-X/2013 on the implementation of the elections, which aims for budget efficiency, influencing commitment to strengthen political parties in permanent coalition to strengthen their power base in state institutions, and also strengthen the presidential system. This research examines the issue of millennial voter generation in the 2019 simultaneous general election. This research use qualitative research methods. The findings of this research are: (1) Millennial generation in the Special Region of Yogyakarta said that most of them get electoral information through social media, (2) The underlying factor for millennial voters came to the polls, which
\end{abstract}


was to realize the election as an important means for democracy, (3) Millennial voters said they have problems, namely confusion in determine their choice at the polling station due to the many candidates who are the effects of the simultaneous election of 5 ballots, (4) Millennial generation admit find the practice of money politics and regard money politics as a matter of course.

Keywords: millennial generation, money politics, voter issues, 2019 simultaneous election

\begin{abstract}
Abstrak
Pembahasan milenial menjadi trend di pemilu serentak 2019, istilah milenial kerap dijadikan sebagai program kegiatan dalam menarik simpati pemilih milenial baik penyelenggara pemilu maupun aktor politik. Penelitian ini meneliti Persepsi pemilih Milenial dalam pemilihan umum serentak 2019. Penelitian ini mengunakan metode penelitian kuantitatif. Hasil temuan penelitian ini yaitu: (1) Generasi Milenial di DIY mengatakan sebagian besar mendapatkan informasi pemilu melalui media sosial, (2) Faktor yang mendasari pemilih milenial datang ke TPS menyadari pemilu sebagai sarana penting bagi demokrasi, (3) Pemilih Milenial mengatakan mengalami kendala kebingungan dalam menentukan pilihannya di TPS akibat banyaknya kandidat calon yang merupakan efek dari pemilu serentak 5 surat suara sekaligus, (4) Generasi Milenial mengakui menemukan praktek politik uang dan menganggap politik uang sebagai hal yang biasa.
\end{abstract}

Kata Kunci : generasi milenial, isu pemilih, pemilu serentak 2019, politik uang 


\section{Pendahuluan}

Istilah milenial menjadi tren banyak kalangan, para politisi mengunakan kata-kata milenial dalam setiap program kampanye atau merubah cara berpakaian mendadak menjadi milenial demi dapat mendapatkan suara pemilih milenial. Sama halnya dari sisi penyelenggara pemilu, program penyelenggara pemilu mendadak merubah kata-kata milenial menjadi sebuah program untuk mengajak pemilu milenial untuk tidak golput dan menjadi bagian pengawasan partisipatif atau biasa disebut pemilih aktif.

Namun istilah milenial yang dipake oleh aktor politik dan penyelenggara pemilu masih hanya sebatas formalitas, banyak dari aktor politik maupun penyelenggara pemilu tidak memahami bagaimana cara berkomunikasi yang baik dalam memberikan pendidikan politik maupun sosialiasi kepada generasi milenial. Cara yang digunakan masih dengan metode lama atau formalitas dalam pemenuhan program kerja. Menurut Rankin (2013) karakteristik milenial berbeda dengan generasi sebelumnya (baby boomers) salah satunya ialah komunikasi kolaborasi bukan satu arah. Artinya informasi yang diberikan tidak hanya satu arah atau monoton namun dikemas dengan model dua arah saling berkolaborasi dan juga dikemas dengan tampilan yang menarik tidak membosankan. Era milenial sangat dekat dengan digital application dewasa ini menjadi isu utama dalam berbagai lini. Akan tetapi di sisi lain, generasi millennial rentan akan social media harassment hingga persoalan cybercrime yang memberikan pengaruh negatif terhadap kematangan pikir generasi muda. Informasi yang didapatkan mereka terkait isu politik lebih besar informasi saling hujat atau menjatuhkan lawan politik dibandingkan informasi mendidik seputar informasi pemilu maupun pendidikan politik yang benar. Survei yang dilakukan oleh Komite Independen Sadar Pemilu prilaku milenial di Daerah Istimewa Yogyakarta (DIY) jumlah pemilih milenial sekitar $52 \%$ pemilih milenial dari jumlah DPT di DIY. Jumlah ini bukan jumlah yang sedikit.

Di Pemilu serentak 2019 ini Milenial masih di rasa menjadi sasaran tembak oleh penyelenggara pemilu dan aktor politik. Menurut Raharjo (2019) Generasi milenial yang memiliki karakter cepat, instan dalam menerima infromasi, tidak loyal dalam sesuatu hal salah satunya ialah partai politik. Pemilih milenial akan dihadapkan pemilu serentak yang begitu rumit, di hadapkan oleh calon legislatif yang begitu banyak, serta minimnya informasi politik yang mendidik didapatkan. Maka penelitian ini akan menjelaskan "PERSEPSI PEMILIH MILLENIAL DALAM PEMILU SERENTAK 2019 DI PROVINSI DAERAH ISTIMEWA YOGYAKARTA"

\section{Metode Penelitian}

Jenis penelitian yang digunakan dalam penelitian ini adalah penelitian kuantitatif dengan pendekatan deskriptif. Metode penelitian kuantitatif merupakan salah satu jenis penelitian yang spesifikasinya adalah sistematis,terencana dan terstruktur dengan jelas sejak awal hingga pembuatan desain penelitiannya.

Penelitian ini mengunakan pendekatan deskriptif dengan tujuan untuk mendeskripsikan objek penelitian ataupun hasil penelitian. Untuk pengumpulan data, ia menggunakan angket/kuisioner 
dengan memberikan 6 pernyataan kepada responden. Penyebaran dilakukan selama 3 hari saat pemungutan suara 17 April 2019 lalu.

Para responden dipilih secara purposif di lima kabupaten dan kotamadya di Daerah Istimewa Yogyakarta (dikenal sebagai Daerah Istimewa Yogyakarta atau DIY) yaitu Kota Yogyakarta, Sleman, Kulonprogo, Bantul, dan Gunung Kidul. Mereka adalah Generasi Milenial yang berusia 17-35 tahun. Memilih lokasi ini sebagai daerah penelitian didasarkan pada pertimbangan bahwa DIY adalah salah satu kota pendidikan di Indonesia yang mengalami perubahan cepat di antara wilayah lain. Oleh karena itu, anak muda di DIY dapat menjadi tolok ukur utama untuk kualitas pandangan anak muda tentang pemilu 2019.

Jumlah responden adalah 400 dari 1.019.965 pemilih muda di DIY. Hasil responden 400 didapatkan hasil dari perhitungan rumus slovin. Berikut perumusan responden melalui perhitungan rumus slovin :

$$
n=\frac{N}{1+N(d)^{2}}
$$

Keterangan:

$$
\begin{aligned}
\mathrm{n} & =\text { besar sampel } \\
\mathrm{N} & =\text { besar populasi } \\
\mathrm{d} & =\text { tingkat signifikansi }
\end{aligned}
$$

$$
\begin{aligned}
& n=\frac{1.019 \cdot 965}{1+1.019 \cdot 695(0,05)^{2}} \\
& n=\frac{1.019 .695}{1+1.019 .695(0,0025)} \\
& n=\frac{1.019 .695}{1+2.549,23}
\end{aligned}
$$

$\mathrm{n}=399.8$ (dibulatkan menjadi 400) setelah mendanpatkan jumlah responden hasil responden di bagi menjadi 5 kabupaten kota secara proposional berikut hasil pembagian wilayah responden masing-masing kabupaten kota:

Tabel 1. Hasil pembagian responden

\begin{tabular}{cc} 
Nama Kabupaten/Kota & Jumlah Responden \\
\hline Kota Yogyakarta & 80 \\
\hline Kab Gunung kidul & 80 \\
\hline Kab Bantul & 80 \\
\hline Kab Sleman & 80 \\
\hline Kab Kulon Progo & 80 \\
\hline
\end{tabular}

Teknik sampling yang digunakan dalam penelitian ini nonprobability sampling dengan teknik purposive sampling. Penulis memilih teknik Purposive Sampling yang menetapkan pertimbangan-pertimbangan atau kriteriakriteria tertentu yang harus dipenuhi oleh sampel-sampel yang digunakan dalam penelitian ini. Dalam hal kriteria responden, responden yang dipilih berusia 17 - 35 tahun dengan syarat masuk dalam kategori pemilih Daftar pemilih tetap (DPT) dan Daftar pemilih tambahan (DPK). Artinya responden memiliki hak 5 surat suara yaitu surat suara calon presiden dan wakil presiden, DPR RI, DPD RI, DPRD Provinsi, DPRD Kabupaten/kota. Penelitian kualitatif ini menggunakan analisis pendekatan Grounded Theory. Grounded Theory merupakan kumpulan prosedur yang sistematis dan mengembangkan pemikiran berlandaskan induktif, tujuan utama dari grounded theory adalah menjelaskan fenomena dengan mengidentifikasi, mengkategori hubungan dan proses dalam penelitian 


\section{Perspektif Teori}

\subsection{Teori Persepsi}

Dalam pandangan Rivai (2009:54) persepsi adalah suatu proses yang ditempuh seseorang atau individu untuk mengorganisasikan dan menafsirkan kesan atau pesan indera mereka agar memberikan makna bagi lingkungan mereka.Persepsi itu agar memberikan makna bagi lingkungan mereka. Persepsi itu penting dalam studi perilaku organisasi karena perilaku orang yang didasarkan pada persepsi mereka mengenai apa itu realitas dan bukan mengenai realitas itu sendiri.
Persepsi pada hakikatnya adalah proses kognitif yang dialami oleh setiap orang di dalam memahami informasi tentang lingkungan nya baik lewat penglihatan, pendengaran, penghayatan, perasaan, dan penciuman. Kunci untuk memahami persepsi adalah terletak pada pengenalan bahwa persepsi itu merupakan suatu penafsiran yang unik terhadap situasi, dan bukannya suatu pencatatan yang benar terhadap situasi.

Proses Pembentukan Persepsi menurutDamayanti (2017:10) digambarkan sebagai berikut:

Tabel 2. Faktor Tebentuknya persepsi

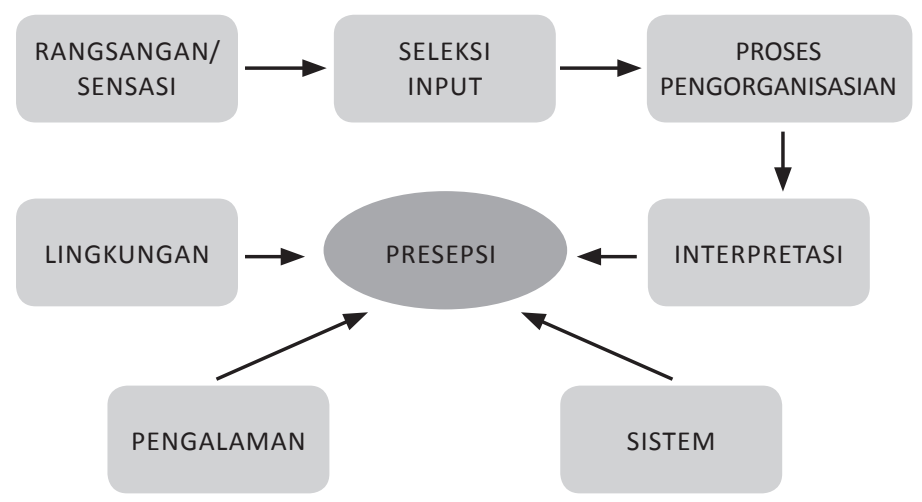

Sumber: diolah oleh Damayanti (2017:10)

Proses pembentukan persepi menurut Damayanti (2017:11) dimulai dengan penerimaan rangsangan dari panca indera yang dimiliki, setelah itu diberikan respon sesuai dengan penilaian dan pemberian arti terhadap rangsang lain. Setelah diterima rangsangan atau data yang ada diseleksi. Untuk menghemat perhatian yang digunakan rangsanganrangsangan yang telah diterima diseleksi lagi untuk diproses pada tahapan yang lebih lanjut. Setelah diseleksi rangsangan diorganisasikan berdasarkan bentuk sesuai dengan rangsangan yang telah diterima. Setelah data diterima dan diatur, proses selanjutnya individu menafsirkan data yang diterima dengan berbagai cara. Dikatakan telah terjadi persepsi setelah data atau rangsang tersebut berhasil ditafsirkan 


\subsection{Generasi Milenial}

Generasi Milenial lahir pada era internet booming dimana banyak digunakan teknologi seperti email, sms, instant message, hingga media sosial yang terhubung dengan internet.

Howe dan Strauss pada tahun 2000 menjelaskan Generasi Milenial lahir pada lahir pada tahun 1982-2000 (Koeller, 2012).

Ciri-ciri umum generasi milenial yaitu Generasi Millenial lebih percaya User Generated Content (UGC), kritis terhadap politik atau pemilu, dengan mendapatkan informasi melalui internet. Dan generasi milenial wajib memiliki media sosial sebagai sarana informasi kehidupan

\section{Hasil dan Pembahasan}

\subsection{Persepsi Generasi Milenial dalam Mendapatkan Informasi Pemilu Serentak 2019}

Persepsi adalah proses seseorang atau individu dan menginterprestasikan stimulasi ke dalam suatu gambaran yang berarti dan koheren dengan dunia sekitarnya. Persepsi merupakan faktor psikologis yang mempengaruhi perilaku seseorang. Dalam ilmu psikologi dan kognitif persepsi adalah proses untuk memperoleh, menginterpresati, menyeleksi dan mengorganisasi informasi. Faktor terjadinya persepsi Pandangan Damayanti (2017:10) menjelaskan proses persepsi dimulai dari penerimaan rangsangan informasi Setelah diteruma rangsangan atau data yang ada diseleksi.
Untuk menghemat perhatian yang digunakan rangsangan-rangsangan yang telah diterima diseleksi lagi untuk diproses pada tahapan yang lebih lanjut. Setelah diseleksi rangsangan diorganisasikan berdasarkan bentuk sesuai dengan rangsangan yang telah diterima. Setelah data diterima dan diatur, proses selanjutnya individu menafsirkan data yang diterima dengan berbagai cara. Dikatakan telah terjadi persepsi setelah data atau rangsang tersebut berhasil ditafsirkan.

Isu pemilu biasanya dibicarakan di media mainstream atau media sosial dan akhirnya dibicarakan oleh siapa saja. Dan akhirnya informasi terkait pemilu menjadi bias dan kebenarannya harus dikonfrimasi oleh pihak yang bersangkutan. Generasi Milenial salah satu Generasi yang sedang menjadi tren dalam bidang pemilu di 2019 ini. Jumlah mereka cukup besar dalam pemilu 2019 ini menjadi incaran banyak pihak, seperti kandidat politik dan penyelenggara pemilu yang mendadak banyak program mengunakan istilah milenial. Karakteristik Milenial yang mudah mencerna semua informasi yang didapatkan ini menjadi salah satu kekhawatiran mendapatkan informasi yang salah. Survei yang dilakukan oleh peneliti Generasi Milenial di Provinsi Daerah Istimewa Yogyakarta sekitar 46\% mengakui mendapatkan informasi terkait Pemilu berasal dari media sosial, $26 \%$ media konvensional, $24 \%$ penyelenggara Pemilu, dan terkecil $4 \%$ berasal dari partai politik. berikut tabel hasil penelitian: 
Tabel 3. Info Tentang Pemilu

\section{INFO TENTANG PEMILIU}

Medos $\square$ Penyelenggara Pemilu $\square$ Parpol $\square$ Media Konvensional (Media Cetak, Radio, dll)

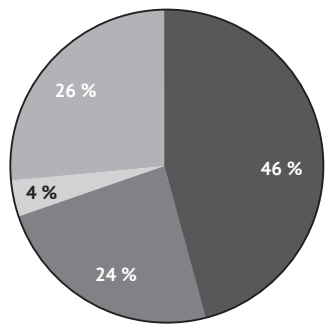

Sumber: diolah penulis

Temuan ini menjadi salah satu tolak ukur bahwa Generasi Milenial mendapatkan informasi pemilu berasal dari media sosial yang justru kebenaran dan kevalidan informasi masih dipertanyakan, apalagi jika mendapatkan informasi pemilu di media sosial yang akunnya dalam kategori akun robot (fake account). Maka kesempatan Generasi Milenial terkena imbas hoax juga cukup tinggi. Informasi yang didapatkan melalui penyelenggara pemilu hanya $24 \%$ dan partai politik $4 \%$ menjadi tugas besar mereka untuk memikirkan konsep literasi politik atau sosialisasi politik dengan mengunakan memanfaatkan media sosial. Media sosial yang di penuhi buzzer yang kebenaran nya tidak bisa di pertanggung jawabkan peran partai politik dan penyelenggara pemilu bisa memaksimalkan instrumen ini untuk memberikan pendidikan politik yang baik. Penyelenggara pemilu memiliki kepentingan untuk memberikan tahapan sosialisasi kepada generasi milenial tentu harus memikirkan konsep penyampaian informasi yang inovatif dan kreatif pada generasi milenial. Sedangkan aktor politik dapat memanfaatkan media sosial sebagai sarana kampanye yang efektif dibandingkan dengan memasang banyak baliho yang belum tentu dipahami oleh generasi milenial.

Menurut Heryanto (2018) Fenomena peralihan komunikasi politik atau informasi politik beralih kepada teknologi digital merupakan kemunculan fenomena "third age of political communication" di mana komunikasi politik beralih ke jaringan internet atau media sosial. Menurut Flew (2005) mendefinisikan ada 3 generasi komunikasi politik, pertama retrorika politik, kedua media mainstream, ketiga media sosial.

Kekhawatiran kesalahan mendapatkan infromasi terkonfrimasi kejadian Pemugutan suara ulang akibat mendapatkan pesan informasi hoax melalui media sosial. banyak kalangan Generasi Milenial mendapatkan informasi melalui pesan Broadcast Whatsapp terkait data pemilih sesuai putusan Mahkamah Konstitusi (MK) yang menyatakan bahwa orang yang tidak memiliki Form A5 (pindah memilih) dapat mengunakan Hak suaranya hanya menunjukan E-KTP saja, tentunya informasi ini merupakan informasi hoax karena berdasarkan putusan MK No 20/ PUU-XV II/2019 yang dapat mengunakan E-KTP saja adalah sesuai dengan domisili KTP. Infromasi hoax melalui media sosial ini mengakibatkan KPPS juga ikut terbawa informasi ini dan mengakibatkan PSU (Pemungutan suara ulang di beberapa wildayah di Daerah Istimewa Yogyakarta. (Temuan KISP)

Dari analisis temuan penelitian di atas bahwa Generasi Milenial mendapatkan Informasi melalui penyelenggara pemilu hanya $24 \%$, justru ini menjadi evaluasi penyelenggara pemilu bahwa sosialisasi yang dilakukan KPU maupun Bawaslu 
belum mampu mengedukasi pemilih khususnya Generasi Milenial, karena bisa disimpulkan Generasi Milenial merupakan pengguna medsos terbanyak maka penyelenggara pemilu harus mampu menghadirkan informasi yang mampu menyasar Generasi Milenial melalui media sosial itu sendiri. Konten sosialisasi kreatif digital yang menarik perhatian pemilih milenial harus dapat dihadirkan oleh penyelenggara pemilu agar pemilih tertarik untuk membaca informasi tahapan pemilu. Selain itu, peran partai politik sangat minim dalam memberikan informasi pemilu kepada pemilih milenial.

\subsection{Faktor Partisipasi Pemilih pada Pemilu Serentak 2019}

Partisipasi menjadi hal yang menarik ketika kita melihat bagaimana partisipasi masyakarat terutama generasi milenial dalam pemilu serentak 2019. Kita dapat melihat dari segi faktor apa saja yang mempengaruhi masyarakat untuk hadir ke Tempat Pemungutan Suara (TPS) dan menggunakan hak pilihnya dalam pesta demokrasi. Kemudian melihat bagaimana generasi milenial sebagai pemegang presentasi hak pilih terbesar mengambil peran partisipasinya. Lalu, yang tidak kalah penting adalah melihat tipologi pemilih pada generasi milenial.

Secara tipologi partisipasi dibagi menjadi tiga (3) menurut Mujani (2007) partisipasi aktif, partisipasi pasif, Gologan putih. Partisipasi aktif pemilih terlibat dan mengikuti dalam proses politik ataupun kebijakan politik. sedangkan partisipasi pasif pemilih hanya sebatas menunaikan kewajiban. Golongan putih kelompok aktif tidak peduli dengan urusan politik
Secara khusus dalam temuan penulis melakukan Pemantauan dan Penelitian terkait hal di atas pada hari pemungutan suara 17 April 2019 yang hasilnya adalah sebagai berikut:

Tabel 4. Faktor Datang ke TPS

\section{FAKTOR DATANG KE TPS}
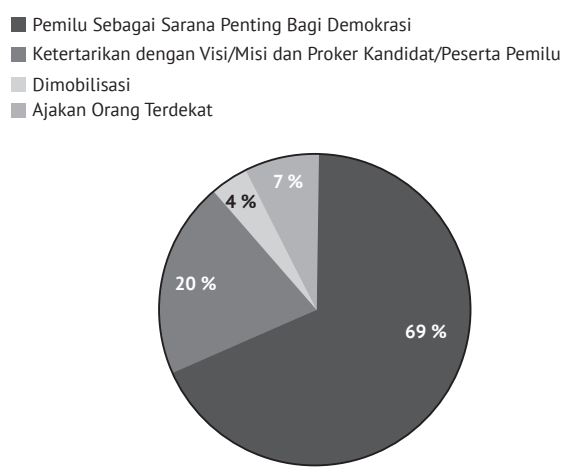

Sumber: Hasil Penelitian Lapangan

Pada Tabel di atas dapat dilihat temuan bahwa kedatangan pemilih ke Tempat Pemungutan Suara (TPS) pada saat pemilu didasari oleh beberapa faktor. Menariknya dari semua faktor tersebut tidak sepenuhnya berasal dari diri pemilih itu sendiri. Antara lain sebanyak 4\% pemilih mengaku datang ke TPS karena ajakan orang terdekat. Adapun pengaruh dari luar lainnya adalah sebanyak 7\% karena mengaku adanya mobilisasi dari kelompok kepentingan tertentu yang menuntun datang ke TPS dengan memilih calon kandidat tertentu. Ironisnya hanya $20 \%$ pemilih datang ke TPS karena tertarik dengan visi misi dari calon kandidat yang akan menjadi wakil atau pemimpin mereka di pemerintahan. Selanjutnya, faktor yang cukup signifikan adalah sebanyak 69\% pemilih menganggap Pemilu sebagai sarana penting bagi demokrasi. Maka terdapat dua permasalahan besar yang perlu menjadi perhatian bersama yaitu: 
a. Pemilu sebagai Sarana Penting bagi Demokrasi

Pemilih Milenial menyadari bahwa pemilu sebagai salah satu bagian penting dalam proses perputaran kepemimpinan yang harus dilalui sebagai negara demokrasi. Dilihat dari sisi tipologi partisipasi fenomena ini masuk dalam fenomena tipologi pasif. Mereka hanya menyadari bahwa pemilu itu penting namun tidak bertindak lebih jauh. Memilih sebagai menunaikan tanggung jawab secara pemahaman utuh mengapa mereka memilih mereka tidak memahami. Sebagai contoh mereka mengetahui lebih dulu visi misi atau latar belakang calon fenomena ini hanya melihat pada output, dalam arti hanya menaati peraturan pemerintah, menerima dan melaksanakan saja setiap keputusan pemerintah.

Kesadaran pentingnya Pemilu sebagai sarana berdemokrasi kerap kali tidak dibarengi dengan pengetahuan mendalam terhadap visi, misi, dan program kerja kandidat. Dibuktikan dengan hasil temuan penulis pada generasi milenial, pemilih milenial memang memiliki tingkat partisipai yang tinggi dalam menggunakan hak suaranya pada Pemilu Serentak 2019, namun mereka justru tergolong kedalang pemilih yang pasif. Mereka hanya terlibat tanpa mengetahui siapa kandidat yang akan mereka pilih, bagaimana program kerja kedepan dan seperti apa visi dan misi yang akan dibangun untuk kesejahteraan rakyat. Generasi milenial menggangap pemilu sebagai sarana mewujudkan demokrasi, namun di sisi lain generasi milenial kekurangan basis informasi untuk menentukan pilihannya. Dengan media yang begitu luas, informasi yang begitu majemuk namun tidak diimbangi oleh edukasi dari partai politik dengan baik, akhirnya generasi milenial menjadi pemilih yang pasif.

b. Minimnya Ketertarikan dengan Visi dan Misi dan program kerja kandidat

Selanjutnya, Angka temuan 20\% pada ketertarikan generasi milenial terhadap visi, misi dan program kandidat Pemilu ini juga menjadi catatan penting bagi partai politik yang dianggap visi misi yang disampaikan tidak dapat diterima dan dipahami dengan baik oleh generasi milenial. Artinya ada komunikasi politik yang kurang baik dari kandidat atau partai politik kepada Generasi Milenial. Komunikasi politik yang dilakukan oleh aktor politik tidak dipahami dengan baik oleh Generasi Milenial. Visi misi yang ditampilkan hanya sebatas formalitas tidak mengena kepada Generasi Milenial.

Rendahnya ketertarikan pemilih dengan Visi, Misi dan Program Kerja Kandidat peserta pemilu menurut penulis didasari Kampanye yang tidak relavan lagi dengan kehidupan sosial masyarakat saat ini. Penyajian kampanye melalalui baliho ataupun spanduk di jalanan sudah tidak menjadi daya tarik suatu kampanye yang menarik lagi dalam pandangan Generasi Milenial. Dengan memasang foto dengan warna yang sama dan gambaran program yang hampir semua nya sama mengakibatkan pemilih milenial justru enggan untuk melirik baliho tersebut dan 
cenderung apatis.

Mengambil inisiatif untuk memaksimalkan media sosial sebagai ranah kampanye sangat cocok untuk menarik simpati Generasi Milenial dalam memberikan pemahaman terkait visi misi dan program. Di sisi lain Kampanye di media sosial lebih murah dan sangat digemari oleh Generasi Milenial karena media sosial salah satu komoditas yang pasti dimiliki oleh Generasi Milenial. Tampilan kampanye yang inovatif, kreatif dan edukatif lebih cocok diterima oleh Generasi Milenial.

Selanjutnya kampanye dengan tatap muka serta melakukan kegiatan yang identik dengan Generasi Milenial juga cocok dibandingkan memasang baliho dan mengatasnamakan Calon Milenial. Karakter dari Generasi Milenial menurut Raharjo (2019) Generasi Milenial memiliki sifat Kolaborasi dibandingkan hanya menjadi pendengar satu arah. Karakter ini bisa dimanfaatkan oleh Aktor Politik maupun penyelenggara pemilu untuk berkolaborasi program dengan Generasi Milenial dibandingkan menerapkan metode ceramah dalam penyampaian materi

Maka dapat ditarik benang merah bahwa partisipasi pemilih milenial dalam pemilu serentak 2019 termasuk ke dalam golongan pemilih pasif yang menyadari bahwa pemilu itu penting sebagai sarana demokrasi. Namun mereka gagal memahami lebih dalam terkait visi, misi, dan program kerja calon anggota legislatif yang aka menjadi representasi mereka. Ini tentu menjadi Pekerjaan rumah bagi banyak pihak, diantara Partai
Politik, kader partai yang menjadi perwakilan, dan juga partisipasi aktif millenial dalam mencari tahu lebih signifikan

\subsection{Kendala Pemilih Milenial di Tempat Pemungutan Suara pada Pemilu Serentak 2019}

Persepsi Pemilih Milenial dalam memandang pemilu serentak 2019 banyak kendala yang mereka hadapi faktor utama sesugguhnya ialah pengetahuan dan pemahaman terkait politik. Serta latar belakang kandidat politik atau visi misi tidak dipahami oleh Generasi Milenial. Dalam temuan penulis Kendala Pemilih Milenial di tempat pemungutan suara sebagai berikut:

Tabel 5. Kendala Pemilih Milenial di Tempat Pemungutan Suara (TPS) KENDALA DI TPS

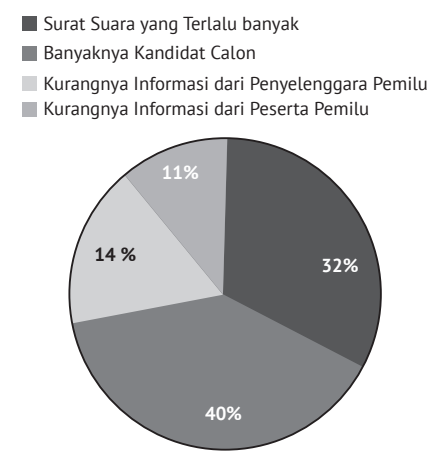

Sumber: Hasil Penelitian Lapangan

a. Banyaknya Kandidat Calon

Data hasil temuan yang dilakukan oleh penulis menyatakan sebanyak $40 \%$ pemilih milenial mengatakan banyaknya kandidat calon menjadi salah satu kendala dalam memilih, setelah itu 32\% mengatakan kendala mereka di TPS adalah karena surat suara yang terlalu banyak, sebanyak 
17\% mengatakan kurangnya informasi dari penyeleggara pemilu, disusul 11\% kurangnya informasi dari peserta pemilu. Dapat dilihat bahwa yang signifikan yaitu sebanyak $40 \%$ pemilih milenial menganggap bahwa banyaknya kadidat calon menjadi kebingungan mereka khususnya di pemilihan legislatif. Isu-Isu yang berkembang hanya selalu membahas pertarungan pilpres yang pada akhirnya isu lokal tertinggal.

Kami melihat harus ada pembenaran sistem Pemilu di Indonesia. Ada opsi lain yang menarik untuk ditawarkan sesungguhnya yaitu pemilu yang dilakukan secara serentak dengan pemisahan pemilu nasional dan lokal. Dalam analisis penulis, pemisahan pemilu nasional dan serentak akan berefek pada pembahasan isu-isu lokal akan menjadi topik pembahasan inti dari partai politik maupun caleg untuk merebut hati pemilih karena pada saat itu suasana dan media sedang menyorot pemilu nasioanl maupun lokal. Pemahaman terkait isu-isu lokal pada pemilu 2019 hampir nyaris tidak menjadi pembahasan yang seksi, isu nasional lebih terasa dibandingkan lokal

Kedua, dengan terjadinya pemilu secara terpisah antara nasional dan lokal serentak, menjadikan durasi antarpemilu menjadi lebih pendek, yang semula sekali selama 5 tahun menjadi dua kali dalam lima tahun dengan tenggang waktu dua sampai tiga tahun. Hal ini tidak saja memudahkan pemilih bersikap rasional, tetapi juga memudahkan pemilih untuk menghukum parpol yang jika parpol hasil pemilu nasional kinerjanya buruk. Mereka dapat menghukum di tingkat daerah. Ketiga. Dengan penyatuan pemilu anggota legislatif dengan pemilihan kepala daerah akan mendorong parpol untuk bersunguh-sungguh melakukan kerjasama dalam memenangkan pemilu. Sebab kader parpol yang menjadi calon DPRD harus melakukan kampanye dengan cara bersamaan melaui parpolnya. Dengan situasi demikian memaksa parpol tidak hanya solid saat pemilu namun juga saat pasca pemilu.

b. Surat Suara yang Terlalu Banyak

Pelaksanaan Pemilu 2019 secara serentak mengharuskan pemilih memilih 5 surat suara dirasa menjadi sebuah hambatan yang dirasakan oleh pemilih, tak terkecuali pemilih milenial. Berdasarkan hasil penelitian penulis, sebanyak $32 \%$ pemilih milenial menganggap bahwa kendala yang dialami mereka adalah banyaknya surat suara yang harus dipilih pada saat di Tempat Pemungutan Suara (TPS). Dengan banyaknya pilihan daftar nama calon legislatif dan pemahaman pemilih milenial yang minim terkait visi, misi, dan latar belakang calon legislatif. Penulis memberikan kesimpulan bahwa banyaknya pilihan dalam daftar surat suara sebagai fenomena Sindrom Warung nasi padang. Pemilih milenial disuguhkan banyak pilihan dan bingung menentukan pilihan.

c. Kurangnya Informasi dari Penyelenggara Pemilu dan Peserta Pemilu

Pada praktiknya, penyelenggara Pemilu dan partai politik dianggap 
belum maksimal dalam memberikan informasi dan mecerdaskan pemilih. Pemahaman-pemahaman mengenai demokrasi, pemilu, Selain itu, kemudahan untuk mendapatkan pemahaman-pemahaman tersebut juga merupakan bagian dari sebuah hak asasi manusia, tidak terkecuali generasi milenial di Indonesia..

Temuan lapangan sebanyak $17 \%$ pemilih milenial menganggap bahwa kendala yang mereka alami pada Pemilu 2019 adalah kurangnya informasi yang diberikan oleh penyelenggara pemilu. Selain penyelenggara pemilu, sebanyak $11 \%$ dari pemilih milenial menganggap bahwa partai politik sebagai peserta pemilu kurang memberikan informasi kepada pemilih milenial. Menjadi Evaluasi bagi penyelenggara pemilu bahwa penyampaian informasi kepada pemilih milenial perlu gaya baru salah satunya melalui media sosial. Dan juga sosialisasi perlu memperhatikan subtansi materi yang tidak monoton. Masih banyak penyelenggara pemilu dalam melakukan sosialisasi hanya sebatas pemenuhan kewajiban program bukan sebuah target keberhasilan secara kualitas

d. Perlunya Pendidikan Politik Jangka Panjang

Peran partai politik dalam hal ini di bidang pendidikan politik tidak berjalan dengan masif atau berkelanjutan. Masyarakat menganggap bahwa jika partai politik sudah bergerak, maka itu tandanya tahun politik akan segera datang. Sayangnya, partai politik saat ini hanya berpikiran musim tanam (kampanye) dan menanti musim panen (perolehan suara pada pemilihan umum). Seharusnya partai politik bukan hanya bekerja lima tahun sekali, namum setiap waktu dalam lima tahun. Pasca pemilihan umum, biasanya kerja-kerja partai politik semakin tidak terlihat. Setelah penghitungan suara dan hasil pemilihan umum muncul, partai politik hanya tinggal menghitung kursi yang kiranya akan didapat.

Pembuat kebijakan (decission makers) juga diharapkan mampu mendesain ulang sistem pemilu yang dirasa gagal dan dianggap sebagai sebuah tragedi demokrasi. Selain banyak jatuhnya korban jiwa baik yang wafat maupun yang sakit, permasalahan-permasalahan teknis juga harus diperhatikan dan dievaluasi.

\subsection{Praktek Politik Uang Dalam Pandangan Generasi Milenial}

Politik uang merupakan momok yang sangat menakutkan bagi proses demokrasi yang ada di Indonesia, politik dan uang adalah merupakan dua hal yang berbeda namun tidak dapat dipisahkan antara satu sama lainnya. Karena untuk berpolitik orang membutuhkan uang dan dengan uang orang dapat berpolitik. Tawarmenawar politik yang tidak didukung pertimbangan kompetensi, akan segera berubah menjadi tawar-menawar dagang biasa yang salah satu wujudnya adalah politik uang.

Dalam pandangan Kumolo (2015) Politik uang merupakan salah satu bentuk suap, yaitu pertukaran uang dengan maksud untuk menentukan posisi seseorang, mengatasnamakan 
kepentingan rakyat namun hanya untuk kepentingan pribadi. Atau politik uang sebagai upaya untuk mempengaruhi orang lain dalam hal ini masyarakat dengan mengunakan imbalan materi dapat diartikan jual-beli suara dalam pemilihan umum atau pemilihan kepala daerah.

Politik uang seakan telah menjadi budaya masyarakat Indonesia ketika menghadapi pesta demokrasi seperti Pemilu dan Pemilihan Kepala Daerah (Pilkada). Budaya ini telah terjadi saat orde baru hingga pasca reformasi. Masyarakat Indonesia memandang pemilu adalah bagian dari kesempatan atau aji mumpung untuk mendapatkan keuntungan uang dari calon legislatif. Ironinya praktik haram ini ditularkan hingga ke generasi yang dianggap sebagai Generasi $Y$ dan Z atau biasa yang sering dikenal sebagai Generasi Milenial. Generasi Milenial ini seakan menjadi sasaran utama para pelaku politik untuk mempengaruhi pilihan suara dengan mengunakan uang.

Dalam penelitian lapangan penulis menemukan bahwa rata-rata Generasi Milenial mengetahui atau melihat praktik politik uang itu terjadi saat pemilu serentak 2019. Berikut temuan:

Tabel 6. Pemberian Politik uang pada pemilu serentak 2019 PEMBERIAN POLITIK UANG

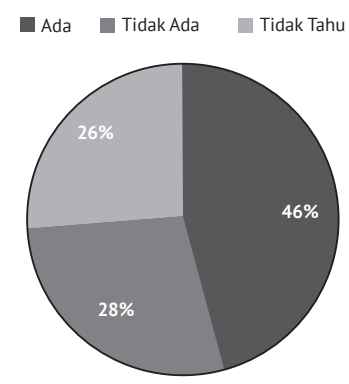

Sumber: Hasil Penelitian Lapangan
Temuan penelitian ini mengisyaratkan bahwa politik uang di DIY sangat marak terjadi, dalam pandangan Muhtadi (2018) dengan mengunakan sistem proposional terbuka akan mengakibatkan persaingan antar caleg baik di internal dan eksternal semakin kompetitif, dan membuat para kandidat mengambil cara untuk melakukan politik uang atau suap. Dalam Pemilu yang diserentakan lima surat suara, mengakibatkan banyaknya calon khususnya di legislatif membuat pemilih menjadi bingung dalam menentukan suaranya. Dalam hasil wawancara kami dengan Generasi Milenial di DIY mereka tidak mengetahui latar belakang calon dan juga visi misi para calon, kebingungan ini di tangkap oleh para politisi dan dimanfaatkan sebagai sasaran politik uang.

Menjadi mengkhawatirkan apabila Generasi Milenial, sebagai penerus bangsa selanjutnya justru tanpa disadari terjangkit praktik politik uang maka pupuslah harapan bangsa Indonesia terbebas dari prilaku korupsi. Penulis mendefinisikan politik uang sebagai salah satu penyakit awal dari terjadinya korupsi. Namun masih banyak Generasi Milenial tidak menyadari dampak dari praktik politik uang ini akan merusak bangsa dan negara. Temuan kami terkait pandangan generasi milenial terhadap politik uang cukup miris, mereka menganggap itu hal yang biasa dalam pemilihan umum dan mereka tidak peduli dengan urusan tersebut. Berikut tabel temuan lapangan: 
Tabel 7. Pandangan terhadap politik uang

\section{PANDANGAN TERHADAP POLITIK UANG}

口 Biasa Saja/Hal yang Wajar Masalah Besar Prihatin

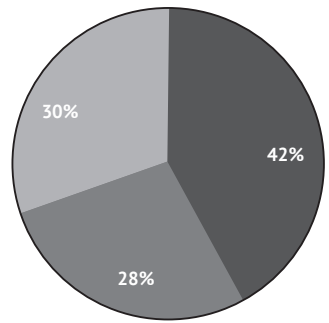

Sumber: Hasil Penelitian Lapangan

Temuan tabel diatas tentu sangat mengkhawatirkan, bahwa generasi milenial masih banyak tidak peduli dengan praktik suap dalam pemilu. Tentu ini menjadi tanggung jawab semua elemen baik pemerintah, penyelenggara pemilu, parpol, dan lembaga swadaya masyarakat (LSM). Literasi politik sangan dibutuhkan Generasi Milenial dalam memandang istilah politik yang luas. Partai politik memiliki kewajiban dalam memberikan pendidikan politik diamanatkan dalam Undang-Undang Nomor 2 tahun 2011 tentang partai politik atas perubahan Undang-Undang nomor 2 tahun 2008 tentang partai politik, Pendidikan Politik adalah proses pembelajaran dan pemahaman tentang hak, kewajiban, dan tanggung jawab setiap warga negara dalam kehidupan berbangsa dan bernegara. Proses penceghan politik uang juga diatur dalam Undang-Undang Nomor 7 Tahun 2017 pasal 93 tugas Badan Pengawas Pemilu ialah mencegah terjadinya politik uang. Artinya pendidikan politik khusunya terkait politik uang Bawaslu memiliki tanggung jawab.

Analisis dari temuan bahwa Generasi Milenial sangat minim dalam mendapatkan literasi politik. literasi politik yang harus didapakan generasi milenial Ada beberapa jenis pengetahuan yang idealnya dimiliki seseorang dan hal tersebut secara politik akan membuat masyarakat melek: pertama, informasi mendasar tentang sejumlah isu, siapa yang memegang kekuatan, dari mana uang tersebut datang, bagaimana sebuah institusi berjalan, kedua bagaimana untuk menjadi terlibat secara aktif menggunakan pengetahuan dan memahami kealamian isu, ketiga bagaimana untuk memprediksi jalan yang paling efektif atas penyelesaian isu, keempat bagaimana untuk mengenali seberapa baik objektif kebijakan telah diraih dan isu-isu yang sudah beres, kelima memahami penyakit-penyakit demokrasi yang merusak bangsa dan negara salah satunya politik uang dan korupsi pemilu.

\section{Simpulan}

Generasi Milenial merupakan generasi yang hidup dalam arus informasi yang serba cepat. Teknologi digital membuat cara prilaku generasi milenial menjadi berubah menginginkan hal yang praktis. Tentu prilaku generasi milenial dalam teknologi akan mempengaruhi cara tindakan partisipasi politik mereka. Menurut Flew (2005) mendefinisikan ada 3 generasi komunikasi politik, pertama retrorika politik, kedua media mainstream, ketiga media sosial. Media sosial sebagai jalan baru untuk mendapatkan informasi khusunya terkait tahapan pemilu dan juga seputar politik. Di sini tentunya pola komunikasi pemerintah, penyelenggara pemilu, partai politik mulai memikirkan konten kreatif digital yang menyasar pemilih milenial. Penyelenggara pemilu 
khususnya Bawaslu dan KPU memberikan pentingya pendidikan pengawasan dan juga tahapan pemilu agar pemilih milenial tidak mendapatkan informasi hoax melalui media sosial. Karena informasi yang tidak valid sumbernya sangat mudah berkeliaran di dunia maya, disinilah pentingnya penyelenggara pemilu suatu lembaga resmi memberikan kebenaran informasi. Demokrasi digital (Cyberdemocracy) merupakan arah baru demokrasi kedepan Indonesia, Bawaslu, KPU, dan partai politik harus merubah gaya komunikasi yang lebih kreatif, inovatif dan kreatif berbasis digital kedepannya. Persoalan politik uang juga menjadi perhatian penting bagi semua kalangan, generasi milenial merupakan harapan untuk memutus rantai budaya korupsi pemilu yang telah mendarah daging. Sikap generasi milenial yang tidak peduli terkait permasalahan politik uang merupakan tanggung jawab penyelenggara pemilu, pemerintah dan partai politik dalam memberikan pendidikan politik. literasi politik bagi kelompok muda atau milenial melibatkan sejumlah hal : pertama mengetahui bagaimana keputusan politik dibuat dalam masyarakat lokal, nasional, internasional, kedua mengembangkan seperangkat pribadi yang memiliki nilai-nilai politik dan memiliki keterampilan serta kepercayaan diri menerapkan dalam praktik, ketiga memahami penyakit demokrasi yang merusak bangsa seperti korupsi pemilu. 


\section{DAFTAR PUSTAKA}

Damayanti. (2017). Faktor Kegagalan Persepsi pada Pembentukan Citra Partisipan dalam Debat Politik di Televisi. Journal Desain.

Flew, T. (2005). New Media: An Introduction, Second edition. Oxford University, 11. Koeller, M. (2012). From Baby Boomers to Generation Y Millennials: Ideas on How Professors Might Structure Classes for this Media Conscious Generation. North American Business Press.

Kumolo, T. (2015). Politik Hukum Pilkada Serentak. Bandung: PT Mizan Publika.

Muhtadi, B. (2018). Buying Votes in Indonesla: partisans, Personal Networks and Winning margins. Australian National University.

Mujani, S. (2007). Muslim demokrat: Islam, budaya demokrasi, dan partisipasi politik di Indonesia pasca Orde Baru. Jakarta: Gramedia Pustaka Utama.

Raharjo, B. (2019). Kaum Milenial dan Emak-Emak Bingung Nyoblos Pileg.

Rankin, D. (2013). US Politics and Generation Y:Engaging the Millennials. USA: Lynne Rienner Publishers.

Rivai, V. (2009). Kepemimpinan Dan Perilaku Organisasi. Jakarta: PT Raja Grafindo Persada. 